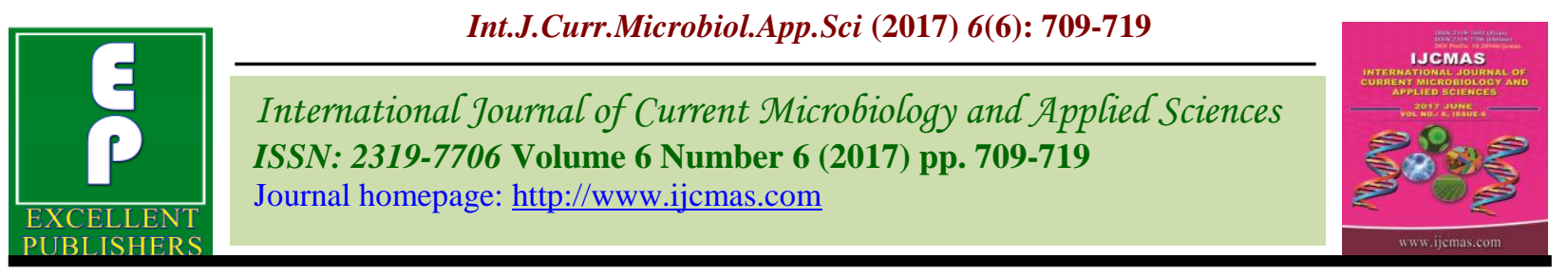

Original Research Article

https://doi.org/10.20546/ijcmas.2017.606.083

\title{
Non-Thermal Preservation of Idli Batter using Sonication
}

\author{
S.P. Prarthana, H.K. Bhatt ${ }^{*}$ and D.C. Joshi \\ College of Food Processing Technology and Bio-energy, \\ Anand Agricultural University, Anand-388 110, Gujarat, India \\ *Corresponding author
}

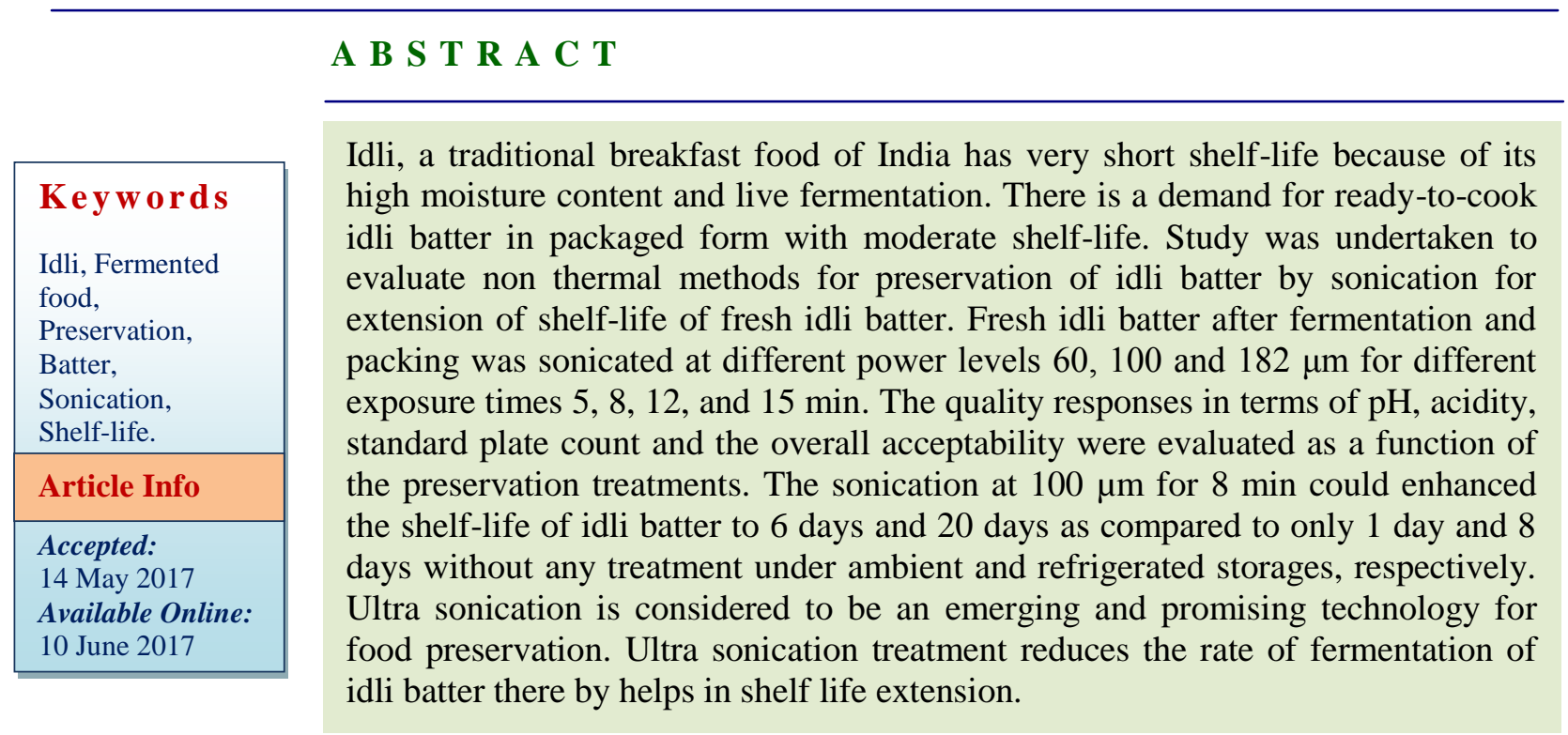

\section{Introduction}

Food is a basic component of eco-system and human beings to select foods from the available bio-resources which are edible. Traditional foods are popularly consumed and form an integral part of our diet since early history. These are prepared in the household or in cottage industry using relatively simple techniques and equipments (Aidoo et al., 2006). India is traditionally rich in fermented foods. In the Indian sub-continent, fermented foods using local food crops and other biological resources are very common (Sekar and Mariappan, 2007). Fermented foods such as idliand dahi were described as early as 700 BC. Each fermented food is associated with a unique group of micro-biota, which increases the level of proteins, vitamins, essential amino acids and fatty acids in the food product. However, fermented foods are still produced traditionally by spontaneous fermentation and only limited knowledge has been obtained regarding the micro-biota of these products (Jeyaram et al., 2009). Cerealbased fermented foods are considered as staple diets in their respective regions. Most of the foods such as idli, dosa, dhokla, koozhu, Nan, parotta, ambali, pazhaiya soru are consumed on the daily basis by the local population. Mostly they are made at household level and have short shelf-life 
(Satish kumar et al., 2012). Idli, a traditional breakfast food of India base on cereal-legume combination, is a white, fermented (leavened), soft, spongy textured product. It's widely consumed in entire South India (Sridevi et al., 2010).

Idli a fermented, thick suspension made by blend of rice (Oryza sativa) and dehulled black gram (Phaseolus mungo). Idli batter has very short shelf-life because of its high moisture content and live fermentation. There is whey separation due to collapse in its volume after a certain period of fermentation which further worsens with storage (Nisha et al., 2005).

Dried idli mixes are the alternatives put in the market. However, because of the inferior texture of the product and its lower organoleptic quality, the instant powders are not popular (Madhura et al., 1998). In general, the thermal techniques of preservation will be suitable for enhancing the shelf-life. However, in case of idli, thermal preservation is not feasible as the batter coagulates or idli is formed on heat application.

Hence only limited alternative technologies can be applied in this case. No systematic studies are available on preservation of idli batter. Hence, the present study was undertaken to evaluate some of the nonthermal methods of preservation for extension of shelf-life of fresh idli batter.

Ultrasonication is considered to be an emerging and promising technology for industrial food processing. It's a non-thermal processing alternative for many liquid food products. When food is exposed to ultrasonication, most of the yeast cells are destroyed. Yeast cells that survive sonication generally lose their ability to grow. This reduces the rate of fermentation substantially.
Thus present study was undertaken with the objective to evaluate the effect of sonication treatment on the shelf-life extension of idli batter.

\section{Materials and Methods}

\section{Raw materials}

Bulk samples of $25 \mathrm{~kg}$ milled rice (Oryza sativa) var. IR 20, and $10 \mathrm{~kg}$ dehulled black gram (Phaseolus mungo) splits were procured from the local market in Anand, Gujarat and stored under ambient conditions.

\section{Preparation of Idli Batter}

Idli batter was prepared using the mixture of milled rice and dehulled black gram split (dhal) in 3:1 ratio. The ratio was selected based on the published literature (Ghosh and Chattopadhyay, 2011; Manohar and Sheety, 2012). The ingredients (rice and dhal) were processed for making idli batter using good manufacturing practices (Agrawal et al., 2000).

Soaking was done in potable water for 6-8 h. After draining the water, rice and black gram were ground, during grinding water was added at 1.5 to 2.0 times the initial weight of the rice and black gram.

The rice was coarsely ground and the black gram was finely ground. The slurries were combined; salt at $2 \%$ was added and stirred manually to form a thick batter. The batter was allowed for fermentation for 8-10 $\mathrm{h}$ at room temperature $\left(30 \pm 2^{\circ} \mathrm{C}\right)$, (Blandino et al., 2003).

\section{Preservation of Idli Batter}

Three different non-thermal technique such as sonication was attempted to enhance the shelf-life of idli batter. The preservation 
treatments were given to the freshly prepared and fermented idli batter before storage.

\section{Sonication of idli batter}

Ultrasound generators $(700 \mathrm{~W}$ and $230 \mathrm{~W}$ powers at $20 \mathrm{kHz}$ ) with an 8 and 6-mm diameter probe (Model Q700, Q Sonica Sonicators Company, USA, and Model VCX 130, Sonics Vibra Cell Company, USA) were used to sonicate idli batter. The amplitude levels selected were 60, 100 and $182 \mu \mathrm{m}$ and exposure times were 5, 8, 12 and $15 \mathrm{~min}$. Two sonicators were used because in Q Sonica equipment, amplitude level more than $100 \mu \mathrm{m}$ is not possible. After sample got sonicated the batter was filled in LDPE bag (300 gauge) and kept for storage studies at ambient temperature $\left(30 \pm 2^{\circ} \mathrm{C}\right)$ or refrigerated $\left(7 \pm 2^{\circ} \mathrm{C}\right)$ storage.

\section{Quality evaluation and shelf life study of idli batter}

All the experiments were conducted and quality responses such as $\mathrm{pH}$ of batter (Ranganna, 1986), total titrable acidity (Iyer and Ananthanarayan, 2008), total microbial count of batter and overall acceptability scores were determined. All the quality measurements were made at every mention day interval for both storage conditions throughout the shelf life.

All experiments were conducted with three replications and the data were subjected to statistical analysis using Factorial Complete Randomized Design and using analysis of variance (ANOVA).

Differences were identified as significant or non-significant based on mean squares and Ftest for significance at $5 \%$ level of each treatment using statistical package software, Design-Expert version 7.0.0 (Stat-Ease Inc., Minneapolis, USA).

\section{Results and Discussion}

Effect of Sonication on Preservation of Idli Batter

The sonicated and stored idli batter was evaluated for different quality attributes as a function of the sonication and storage conditions, Table 1 through 4 show the data of different quality characteristics such as $\mathrm{pH}$, acidity, SPC and overall acceptability of stored idli batter after sonication.

The ANOVA for each response is also appended with the tables.

The samples at $182 \mu \mathrm{m}$ sonication and for time more than 5 min got charred during the sonication. Therefore, the data for 8, 12 and $15 \mathrm{~min}$ at $182 \mu \mathrm{m}$ treatment could not be collected. Hence practically only two levels of sonication $(60$ and $100 \mu \mathrm{m})$ were compared. Similarly when the treatment was inadequate, the samples during storage got spoiled.

The spoilage was in the form of either mold growth or gas formation. The quality evaluation of the charred or the spoiled samples could not be done and hence those data in the tables and figures are missing.

The variations in the quality parameters of the sonicated idli batter during storage. From the statistical analysis, it was observed that all the three parameters (amplitude level, sonication time and storage period) significantly (at 5\% level) affected the quality and the shelf-life of the idli batter.

For understanding the response of each quality attribute to the preservation treatment given, the influence of sonication conditions on $\mathrm{pH}$, acidity and $\mathrm{SPC}$ is described in details here under. 
Effect of sonication and storage on $\mathrm{pH}$ of idli batter

\section{Effect of sonication amplitude}

As the amplitude of sonication was decreased from 100 to $60 \mu \mathrm{m}$, the $\mathrm{pH}$ of the stored idli batter decreased for many samples for all the times of sonication and for both the ambient and refrigerated storages. The $\mathrm{pH}$ values for the samples treated at $182 \mu \mathrm{m}$ were slightly higher than the other treatments in many of the samples. The $\mathrm{pH}$ which was about 4.71 before sonication, immediately dropped to about 4.62 when sonicated for $5 \mathrm{~min}$ at $60 \mu \mathrm{m}$ amplitude (Table 1). Though, the trend in variation is not definite, in majority of the cases, the $\mathrm{pH}$ value increased on increasing severity of sonication. This may be because of the possible liberation of acid from the microbes which might have been destructed during sonication.

\section{Effect of sonication time}

As the time of sonication was increased, the $\mathrm{pH}$ of the treated and stored idli batter increased in most of the cases (Table 1). The trend was similar for all most all the amplitude levels and all the storage periods. As mentioned earlier the $\mathrm{pH}$ value of the sample decreased immediately after sonication. As the batter was treated at $60 \mu \mathrm{m}$, there was increasing in trend of $\mathrm{pH}$ for all sonication times. Again, during the refrigerated storage, the $\mathrm{pH}$ of the sample increased with the increase in time of sonication. This might be possibly due to the fact that as the sonication treatment was prolonged, the microbial destruction might have been more resulting in relatively less reduction in $\mathrm{pH}$ during storage.

\section{Effect of storage conditions}

The $\mathrm{pH}$ value of the sonicated sample decreased during storage both under ambient and refrigerated conditions. This was true for almost all the combinations of sonication. Again, the $\mathrm{pH}$ of the non-sonicated ample also reduced during storage (Table 1).

The value of the $\mathrm{pH}$ decreased to the level of about 3.02 from the original of 4.71, the reduction in $\mathrm{pH}$ during the storage which is obvious due to the fact that the acidity of the fermented product during the storage will increase. However, from the data, it is clear that the reduction in $\mathrm{pH}$ is quite fast under ambient storage as compared to the refrigerated samples treated with similar sonication. This implies that the fermentation continued, though at slower rate during storage.

\section{Effect of sonication and storage on acidity of idli batter}

\section{Effect of sonication amplitude}

As the amplitude of sonication was increased from 60 to $100 \mu \mathrm{m}$, the acidity of the stored idli batter decreased for all samples for almost all times of sonication and for both the ambient and refrigerated conditions. The samples treated at $182 \mu \mathrm{m}$, behaved slightly differently. Again for longer sonication treatment $(15 \mathrm{~min})$, the trend reversed in some of the samples (Table 2). The acidity which was about 2.74 before sonication, immediately dropped to about 2.70 when the sample was sonicated for $5 \mathrm{~min}$ at $60 \mu \mathrm{m}$. There was clear indication that at $60 \mu \mathrm{m}$ sonication, the treatment was not effective to arrest the increase in acidity of the sample during storage.

\section{Effect of sonication time}

The acidity of the treated and stored idli batter decreased in most of the cases (Table 2) as the time of sonication was increased. The trend was similar for all most all the amplitude 
levels and all the storage periods. This might have been because of the possible destruction of more microbes at longer time of sonication, which in term during the storage generated less amount of acidity. The acidity levels of the samples stored under refrigerated conditions were lower at the corresponding period of storage as compared to for those samples stored for similar period of storage under ambient conditions. The fermentation of batter might have been slower under refrigerated storage.

\section{Effect of storage conditions}

The acidity value of the sonicated sample increased during storage under both ambient and refrigerated conditions. This was true for almost all the combinations of sonication. Again, the acidity of the non-sonicated sample also increased during storage (Table 2 ). The value of acidity increased to the level of about 4.3 from the original of 2.74. The rapid increase in the acidity of the treated idli batter during storage indicates inadequacy of the preservation treatment given. The situation is true particularly for the low amplitude levels and for shorter time of sonication and under ambient storage. The rate of increase in acidity during refrigerated storage was slower as compared to that under ambient storage. This might be due to the slower fermentation at lower temperature of the batter.

\section{Effect of sonication and storage on SPC of idli batter}

\section{Effect of sonication amplitude}

As the amplitude of sonication was increased, the total microbial count of the stored idli batter decreased for all most all times of sonication and for both the ambient and refrigerated storages. The microbial count in the non-sonicated idli batter was quite higher than the treated samples. This indicates that amount of the microbial activity has been retarded due to the sonication. This may be because of the destruction of cell wall of microbes due to cavitation occur inside the cell wall of microbes during sonication. At the higher level of amplitude, more microbes might have been destructed.

\section{Effect of sonication time}

The microbial count of the treated and stored idli batter decreased as the time of sonication was increased in all the cases (Table 3). The trend was similar for all most all the amplitude levels and all the storage conditions. The data indicate that the microbial count in the treated samples decreased when the amplitude of the sonication was increased and also as the sonication time was prolonged. The possible reasons have been mentioned earlier. However, the effect of sonication is clearly seen when the data are compared with the non-sonicated samples.

It is evident that the total microbial count in the refrigerated stored samples were quite low than that in samples stored under ambient conditions for similar period. The sonicated samples could be very well stored for adequate time, particularly under refrigerated conditions (Table 3).

\section{Effect of storage}

The SPC of the sonicated sample increased during storage both under ambient and refrigerated conditions. This was true for almost all the combinations of sonication. Again, the SPC of the non-sonicated samples were higher than that of the treated samples for the corresponding storage period (Table 3 ). The trend is obviously due to the possible continuation of fermentation during the storage. 
Int.J.Curr.Microbiol.App.Sci (2017) 6(6): 709-719

Table.1 Effect of sonication and storage on $\mathrm{pH}$ of Idli batter

\begin{tabular}{|c|c|c|c|c|c|c|c|c|c|c|c|c|c|}
\hline \multirow{2}{*}{\multicolumn{2}{|c|}{$\begin{array}{r}\text { Sonication } \\
\text { Storage } \\
\text { Period (days) }\end{array}$}} & \multirow[b]{2}{*}{$\begin{array}{l}\text { No } \\
\text { sonic }\end{array}$} & \multicolumn{4}{|c|}{$60 \mu \mathrm{m}$} & \multicolumn{4}{|c|}{$100 \mu \mathrm{m}$} & \multicolumn{3}{|c|}{$182 \mu \mathrm{m}$} \\
\hline & & & \multirow{2}{*}{$\begin{array}{l}5 \mathrm{~min} \\
4.62\end{array}$} & $8 \mathrm{~min}$ & $12 \min$ & $15 \mathrm{~min}$ & $5 \mathrm{~min}$ & $8 \mathrm{~min}$ & $12 \min$ & $15 \mathrm{~min}$ & $5 \mathrm{~min}$ & \multicolumn{2}{|c|}{$8 \mathrm{~min}$} \\
\hline \multirow{5}{*}{$\begin{array}{l}\text { Ambient } \\
\left(30 \pm 2^{\circ} \mathrm{c}\right)\end{array}$} & 0 & 4.71 & & 4.64 & 4.72 & 4.76 & 4.68 & 4.74 & 4.81 & 4.89 & 4.72 & \multirow{9}{*}{ 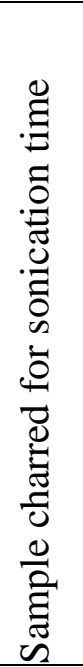 } & \\
\hline & 2 & $* *$ & 4.44 & 4.48 & 4.51 & 4.57 & 4.60 & 4.67 & 4.72 & 4.76 & 4.70 & & \\
\hline & 4 & $* *$ & $* *$ & $* *$ & $* *$ & $* *$ & 4.58 & 4.61 & 4.68 & 4.73 & 4.67 & & \\
\hline & 6 & $* *$ & $* *$ & $* *$ & $* *$ & $* *$ & $* *$ & 3.35 & 3.56 & 3.78 & 3.98 & & \\
\hline & 8 & $* *$ & $* *$ & $* *$ & $* *$ & $* *$ & $* *$ & $* *$ & $* *$ & $* *$ & $* *$ & & \\
\hline \multirow{4}{*}{$\begin{array}{l}\text { Refrigerated } \\
\left(7 \pm 1^{\circ} \mathrm{c}\right)\end{array}$} & 5 & 4.56 & 4.32 & 4.41 & 4.54 & 4.67 & 4.36 & 4.46 & 4.62 & 4.74 & 4.54 & & \\
\hline & 10 & 4.01 & 3.93 & 4.14 & 4.35 & 4.23 & 4.01 & 4.22 & 4.46 & 4.58 & 4.26 & & $n$ \\
\hline & 15 & 3.87 & 3.78 & 3.96 & 4.02 & 3.99 & 3.95 & 4.06 & 4.21 & 4.36 & 4.19 & & 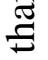 \\
\hline & 20 & $* *$ & 3.02 & 3.34 & 3.46 & 3.61 & 3.38 & 3.57 & 3.68 & 3.88 & 4.05 & & ठே \\
\hline & & \multicolumn{2}{|c|}{ Source } & \multicolumn{2}{|c|}{ D.F } & M.S & $\mathrm{FV}$ & lue & S.Em & & Test & & \\
\hline & & & & & & 3.91 & 9.2 & & 0.35 & & $*$ & & \\
\hline ANOVA & & & & & & 4.516 & & & & & & & \\
\hline & & & & & & & & & & & & & \\
\hline
\end{tabular}

* Significant at $5 \%$ level of significance

** Samples spoiled 
Int.J.Curr.Microbiol.App.Sci (2017) 6(6): 709-719

Table.2 Effect of sonication and storage on acidity (\% TTA) of idli batter

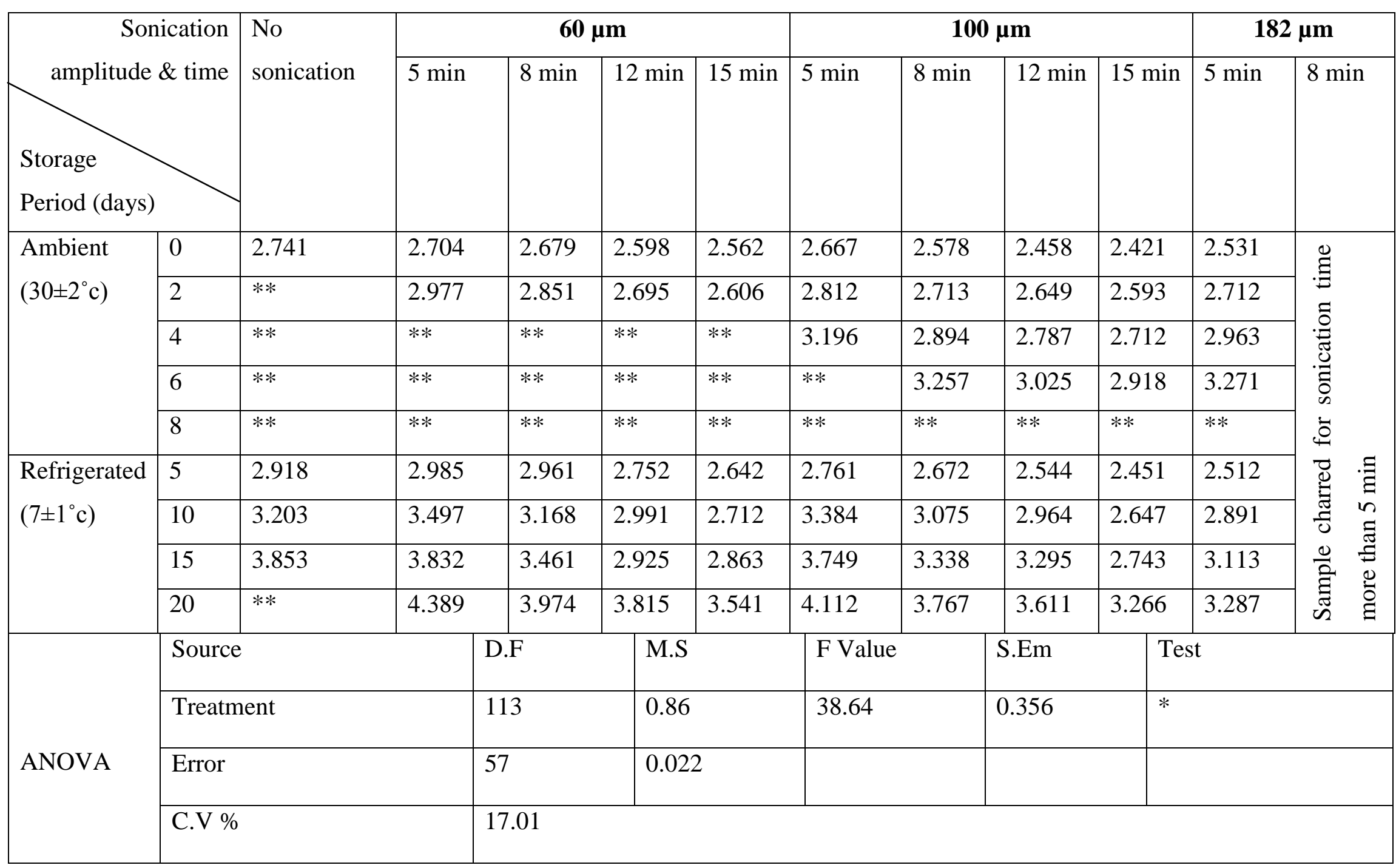

* Significant at $5 \%$ level of significance

** Samples spoiled 
Table.3 Effect of sonication and storage on SPC $\left(10^{7} \mathrm{cfu} / \mathrm{g}\right)$ of idli batter

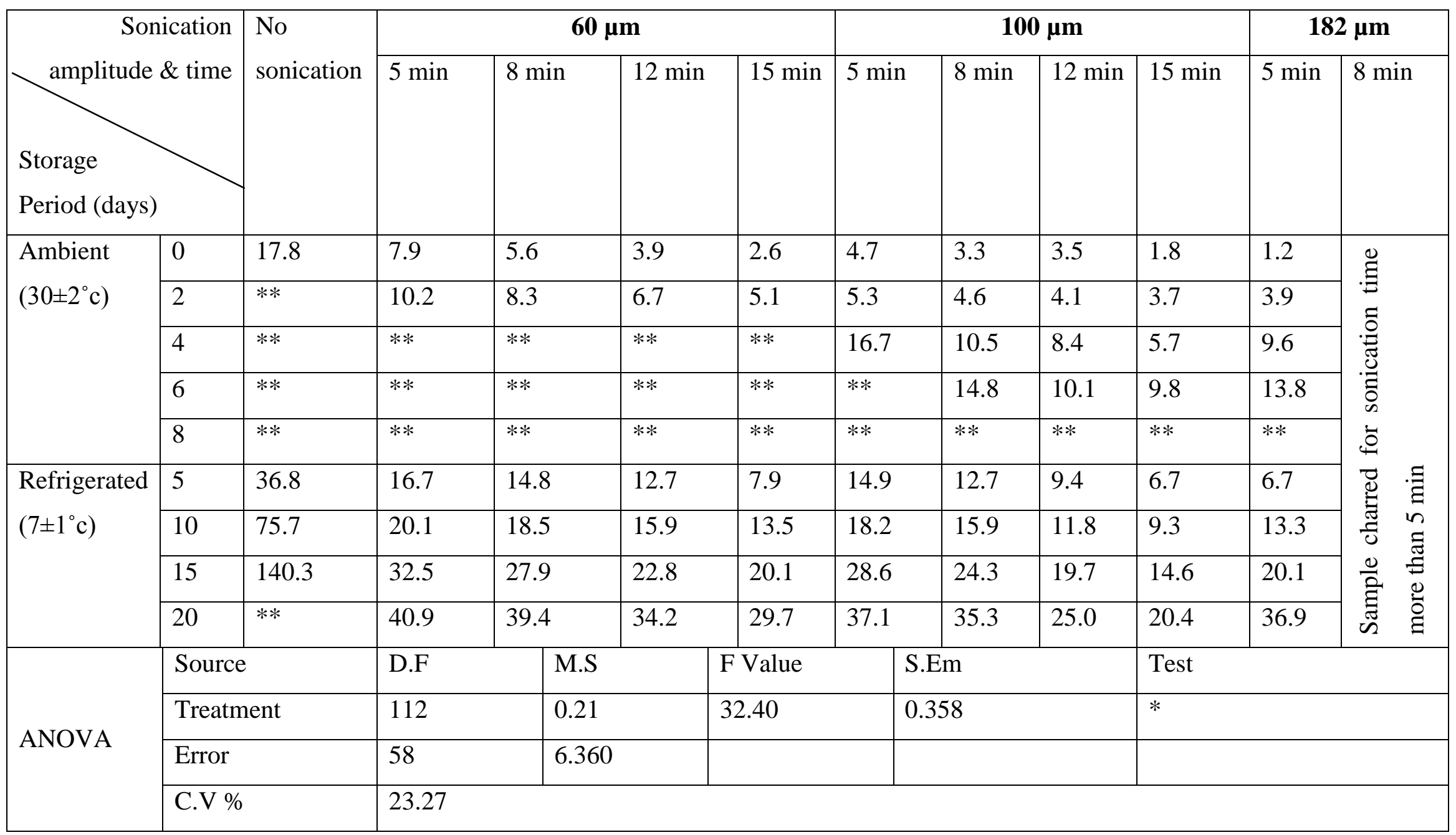

* Significant at $5 \%$ level of significance

** Samples spoiled 
Table.4 Overall acceptability score of sonicated and stored idli batter

\begin{tabular}{|c|c|c|c|c|c|c|c|c|c|c|c|c|c|}
\hline \multirow{2}{*}{\multicolumn{2}{|c|}{$\begin{array}{l}\text { Sonication } \\
\text { amplitude \& time } \\
\text { Storage } \\
\text { Period (days) }\end{array}$}} & \multirow{2}{*}{$\begin{array}{l}\text { No } \\
\text { sonication }\end{array}$} & \multicolumn{5}{|c|}{$60 \mu \mathrm{m}$} & \multicolumn{4}{|c|}{$100 \mu \mathrm{m}$} & \multicolumn{2}{|c|}{$182 \mu \mathrm{m}$} \\
\hline & & & $5 \mathrm{~min}$ & \multicolumn{2}{|c|}{$8 \mathrm{~min}$} & $12 \mathrm{~min}$ & $15 \mathrm{~min}$ & $5 \mathrm{~min}$ & $8 \min$ & $12 \mathrm{~min}$ & $15 \mathrm{~min}$ & $5 \mathrm{~min}$ & $8 \mathrm{~min}$ \\
\hline \multirow{4}{*}{$\begin{array}{l}\text { Ambient } \\
\left(30 \pm 2^{\circ} \mathrm{c}\right)\end{array}$} & 0 & 8.9 & 8.0 & 8.1 & & 8.2 & 8.4 & 8.5 & 8.6 & 8.6 & 8.8 & 8.6 & \multirow{8}{*}{ 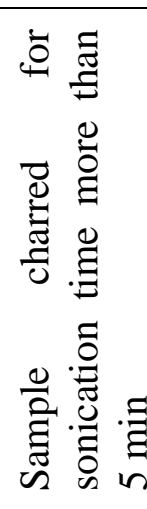 } \\
\hline & 2 & $* *$ & 7.8 & 8.0 & & 8.1 & 8.2 & 7.9 & 8.3 & 8.4 & 8.6 & 8.4 & \\
\hline & 4 & $* *$ & $* *$ & $* *$ & & $* *$ & $* *$ & 6.4 & 6.5 & 6.6 & 6.8 & 7.2 & \\
\hline & 8 & $* *$ & $* *$ & $* *$ & & $* *$ & $* *$ & $* *$ & $* *$ & $* *$ & $* *$ & $* *$ & \\
\hline \multirow{4}{*}{$\begin{array}{l}\text { Refrigerated } \\
\left(7 \pm 1^{\circ} \mathrm{c}\right)\end{array}$} & 5 & 8.1 & 6.8 & 7.1 & & 7.5 & 8.2 & 8.5 & 8.6 & 8.7 & 8.8 & 8.9 & \\
\hline & 10 & 6.4 & 5.7 & 6.0 & & 6.3 & 6.9 & 6.3 & 6.4 & 6.9 & 7.3 & 7.4 & \\
\hline & 15 & 4.9 & 5.2 & 5.5 & & 5.8 & 6.1 & 5.8 & 6.1 & 6.4 & 6.7 & 6.5 & \\
\hline & 20 & $* *$ & 3.7 & 4.8 & & 5.4 & 5.7 & 3.9 & 5.0 & 5.6 & 5.9 & 5.4 & \\
\hline
\end{tabular}

* Significant at $5 \%$ level of significance

** Samples spoiled 
The rapid increase in the SPC of the treated idli batter during storage indicates inadequacy of the preservation treatment given as in some of the samples.

The situation is true particularly for the low amplitude levels and for shorter time of sonication and under ambient storage. The rate of increase in SPC during refrigerated storage was slower as compared to that under ambient storage. This might be due to the slower fermentation at lower temperature of the batter during storage.

\section{Effect of sonication and storage on overall acceptability of idli batter}

\section{Effect of sonication amplitude}

As the amplitude of sonication was decreased from 100 to $60 \mu \mathrm{m}$, the overall acceptability of the stored idli batter decreased for many samples for all the times of sonication and for both the ambient and refrigerated storages. The overall acceptability scores for the samples treated at $182 \mu \mathrm{m}$ were slightly higher than the other treatments in many of the samples. The overall acceptability for fresh batter was about 8.9 score before sonication, immediately dropped to about 8.0 when sonicated for $5 \mathrm{~min}$ at $60 \mu \mathrm{m}$ amplitude. Though, the trend in variation is not definite, in majority of the cases, the overall acceptability score decreased on sonication.

\section{Effect of sonication time}

As the time of sonication was increased, the overall acceptability of the treated and stored idli batter increased in most of the cases (Table 4). The trend was similar for all most all the amplitude levels and all the storage periods. As mentioned earlier the overall acceptability score of the sample decreased immediately after sonication. As the batter was treated at $60 \mu \mathrm{m}$, there was increasing in trend of overall acceptability score for all sonication times. Again, during the refrigerated storage, the overall acceptability score of the sample increased with the increase in time of sonication.

\section{Effect on storage conditions}

The overall acceptability score of the sonicated sample decreased during storage both under ambient and refrigeration conditions. This was true for almost all the combinations of soniaction. Again, the scores of the nonsonicated sample also decreased during storage (Table 4). The trend is obviously due to the decrease in $\mathrm{pH}$ and increase in acidity of the batter during storage. The rate of decrease in score during refrigerated storage was slower as compared to that under ambient storage

\section{Shelf-life of sonicated idli batter}

The shelf-life of the treated idli batter with different conditions of sonication and subsequently stored under both the ambient and refrigerated conditions. The value of the storage period for which the overall acceptability of the stored sample was more than 6.0 and it was computed in days using the mathematical relationships. The shelf-life of the idli batter increased on sonication. The increase was higher under refrigerated conditions. The shelflife also increased with the increase in sonication amplitude for most the sonication times. The longest shelf-life obtained was 6 days $(100 \mu \mathrm{m} \& 8 \mathrm{~min})$ and 20 days $(100 \mu \mathrm{m} \&$ $15 \mathrm{~min}$ ) under ambient and refrigerated storage, respectively as compared to only 1day and 8 days for samples without sonication. It is substantial increase in shelf-life. If the freshfermented idli batter is sonicated immediately at $100 \mu \mathrm{m}$ for about $8 \mathrm{~min}$, then the shelf-life could be increased almost six times at ambient storage itself. This will help in increasing the production and consumption of idli batter.

As the sonication amplitude and sonication time was increased, the $\mathrm{pH}$ of the stored idli batter increased under both ambient and refrigerated conditions. The reduction in $\mathrm{pH}$ was quite fast under ambient storage as compared to the refrigerated samples treated with similar 
sonication. The acidity of the idli batter stored under both ambient and refrigerated storage is reduced on increasing the sonication amplitude and time of sonication. The acidity of the sonicated idli batter increased during storage. As the sonication amplitude and sonication time was increased, the SPC of the stored idli batter reduced under both ambient and refrigerated conditions. The SPC of the sonicated batter increased during the storage. The overall acceptability of the idli prepared from sonicated and stored batter, improved when the batter was sonicated at higher amplitude for longer period, the sensory quality deterioted during the storage of sonicated batter. The shelf-life of idli batter increased on sonication as compared to only 1 day and 8 days without any treatment under ambient and refrigerated storages, respectively.

\section{References}

Agrawal Renu, Rati, E.R., Vijayendra, S.V.N., Varadaraj, M.C., Prasad, M.S. and Krishnanand. 2000. Flavour profile of idli batter prepared from defined microbial starter cultures. World J. Micro. \& Biotech. 16(7): 687-690.

Aidoo, K.E., Nout, N.J.R. and Sarkar, P.K. 2006. Occurance and function of yeasts in Asian indigenous fermented foods. FEMS, 6(1): 30-39.

Blandinob, A., Al-Aseeria, M.E., Pandiellaa, S.S., and Canterob, D., Webba, C. 2003. Cereal-based fermented foods and beverages. Food Res. Intl., 36(6): 527543.

Ghosh Debasree and Chattopadhyay Parimal. 2011. Preparation of idli batter, its properties and nutritional improvement during fermentation. J. Food Sci. Technol., 48(5): 610-615.

Iyer, K., Bharthi and Laxmi Ananthanarayan. 2007. Effect of a-amylase addition on fermentation of idli-A popular south Indian cereal-Legume-based snack food. Lebensmittel-Wissenschaft and Technologie. LWT. Food Sci. Technol., 41(6): 1053-1059.

Jeevaratnam, K., Jamuna, M. and Bawa, A.S. 2005. Biological preservation of foods Bacteriocins of lactic acid bacteria. Indian J. Biotechnol., 4: 446-454.

Jeyaram, K., Singh, A., Romi, W., Devi, A. R., Singh, W.M. and Dayanithi, H. 2009. Traditional fermented foods of Manipur. Indian J. Traditional Knowledge, 8(1):115-121.

Manohar Durgadevi and Shetty. H. Prathapkumar. 2012. Effect of ingredients on texture profile of fermented food, Idli. $3 r d$ International Conference on Biotechnology and Food Science. ICBFS, 2: 190-198.

Satish Kumar, R., Kanmani, P., Yuvaraj, N., Paari, K.A., Pattukumar, P. and Arul, V. 2012. Traditional Indian fermented foods: a rich source of lactic acid bacteria. Int. $J$. Food Sci. Nutri., 1-14.

Sekar, S. and Mariappan, S. 2007. Usage of traditional fermented products by Indian rural folks and IPR. Indian J. Traditional Knowledge, 6(1): 111-120.

Sridevi, Prakash, M. Halami and Vijayendra, S.N.V. 2010. Selection of starter cultures for idli batter fermentation and their effect on quality of idlis. J. FST, 47(5): 557563.

\section{How to cite this article:}

Prarthana, S.P., H.K. Bhatt and Joshi, D.C. 2017. Non-Thermal Preservation of Idli Batter using Sonication. Int.J.Curr.Microbiol.App.Sci. 6(6): 709-719. doi: https://doi.org/10.20546/ijcmas.2017.606.083 